\title{
A Remarkable New Genus and Three New Species of Cavernicolous Carabidae (Coleoptera) (Zoological Results of the British Speleological Expedition to Papua-New-Guinea 1975, 2)
}

by

B. P. MOORE*

Although the extensive cave-systems of Papua-New Guinea have been investigated previously to a limited extent, by biologically orientated speleologists, captures of carabid beetles have been confined to a few unremarkable species of the tribe Agonini (e.g., Altagonum misim Darl. (Darlington, 1971)) that also occur widely in surface habitats. The material collected during the recent British speleological expedition to the area, however, includes two blind species of this locally dominant tribe that are evidently highly adapted troglobites, thus adding an entirely new and zoogeographically important element to the carabid fauna. For the opportunity to study this interesting material, I am greatly indebted to Dr. P. Beron and at his request, holotypes of the three new species will be placed in the Institute of Zoology, Sofia.

\section{SPEAGONUM Gen. n.}

A genus of troglobitic Agonini, with the following character states:

Head with two supraorbital beside each eye; mentum strongly toothed; palpi slender, glabrous; antennae slender, the third segment arcuate, shorter than the fourth. Pronotum without marginal setae; prosternal process asetose; metepisterna elongate. Elytra free, dehiscent and \pm mucronate at apex; third intervals with two discal pores; hindwings absent. Femora rounded on underside; tarsi slender, segments 1-4 bisulcate; fourth segment weakly bilobed; claws simple. Aedeagus well sclerotised, membranous over much of dorsum; parameres conchoid, glabrous. Wing-and-seta-formula (cf. Darlington, 1952): $-\mathrm{w},++,-$ + - .

Type species: Speagonum mirabile sp. n. (New Guinea).

Within the Australasian fauna, this new genus is unique in its marked adap-

*) CSIRO, Division of Entomology, Canberra, Australia. 
tations to a cavernicolous existence, notably the attenuate body form and the extremely long and slender appendages. In terms of wing-and-seta-formula it is perhaps closest to Laevagonum Darl. which, however, lacks elytral discal setae. The type species, Speagonum mirabile, is remarkably similar in habitus to troglobitic species of the American genus Rhadine Leconte but this resemblance may well be due to convergent evolution. The latter species, known from the southern United States and from Mexico, are, however, more or less pubescent, with pubescent palpi; the femora are flattened beneath; and the third antennal segments are straight and longer than the fourth segments (Barr, 1960).

\section{SPEAGONUM MIRABILE sp. n. (Figs. 1, 4)}

Elongate; foreparts very attenuate; appendages extremely long and slender. Body dark brown to pitchy-black (lighter in immature specimens), the appendages lighter, yellowish-brown; rather shagreened, the microsculpture fine but marked.

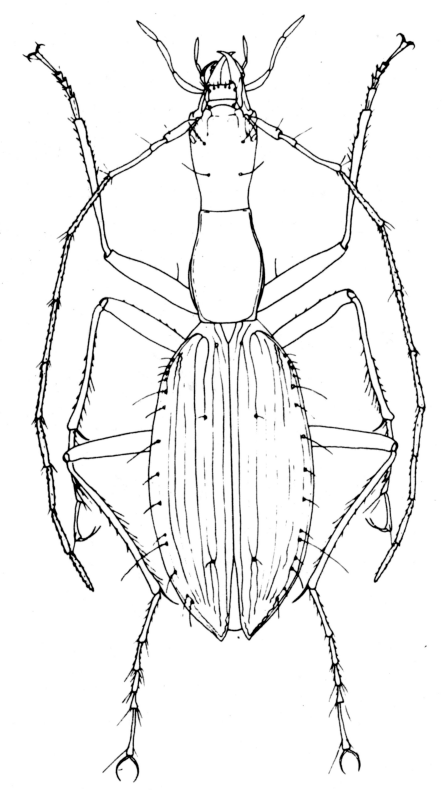

Fig. 1. Speagonum mirabile gen. et sp. n., paratype female.

Head elongate; neck pronounced but not abrupt; mandibles long, slender, porrect; eyes reduced to small flat scars, without facets; frontal furrows wide and shallow; vertex with a shallow circular depression; labrum transverse, 6setose, the inner 4 setae submarginal, the outer 2 submedian; tooth of mentum simple; antennae long, filiform, reaching the apices of the elytra in repose. Pro- 
notum fusiform, scarcely wider than head; apex lightly emarginate; base truncate; anterior angles rounded, not prominent; posterior angles bluntly rectangular; swollen sterna visible from above; marginal channels discernible but narrow except near base; basal foveae shallow, elongate. Elutra elongate; humeri largely effaced, very oblique; striae fine but cleanly incised for much of their length, impunctate; intervals flat, markedly shagreened; third intervals with two pores, the anterior rather variable in location but set against third stria, the posterior bridging and distorting the interval at the hind quarter; epipleurae narrow and obsolete well before apex; abdomen smooth, the segments with two prominent setae about the midline, in male, the terminal usually 4-setose in female; legs very long and slender; onychium glabrous beneath; male anterior tarsi with three basal segments weakly expanded and squamose beneath; median lobe of aedeagus regularly curved, laterally, acuminate in dorsal view. Length (including mandibles): $9.5-11 \mathrm{~mm}$; maximum width: about $3 \mathrm{~mm}$ (elytra slightly distorted through storage in spirit).

Holotype ô, Okemimal tem Cave, Behrman Mountains, near Tifalmin, W. Sepic Province, NEW GUINEA, P. Beron and P. Chapman, 15.x1975. Paratypes $2 \circ \dot{q}$, from nearby Selminum tem Cave, same collectors, xi.1975; 1 \& ,F tem Cave, same collectors, 9.xi.1975. One paratype will be deposited in the British Museum (Natural History), London and the others will be retained for the present in the author's collection. Additional topotypical material is expected to be available for study and distribution, later, when the bulk of the Carabidae resulting from the Expedition has been fully sorted.

\section{GASTRAGONUM CAECUM sp. n. (Fig. 2)}

Piceous-brown, the appendages and margins of the pronotum lighter, reddishbrown; rather polished, the microsculpture very fine.

Head elongate; neck pronounced and rather abrupt; mandibles long, slender, porrect; eyes reduced to flat scars without facets; frontal furrows short, foveiform; labrum transverse, the apex bisinuate and 6-setose; tooth of mentum obtusely rounded; antennae long, filiform, reaching about the hind quarter of the elytra in repose. Pronotum orbicular; anterior and posterior angles rounded and slightly prominent; margins widely explanate; median line rather deep; basal foveae broad, shallow, striolate. Elytra elongate-oval; humeri rounded but obvious; apices rounded, unarmed; striae well impressed on disc, impunctate; third and fourth and fifth and six th striae uniting towards apex to become irregularly catenulate; intervals convex; third intervals with three pores; hindwings vestigial or absent; apex of female abdomen 4-setose; legs long and slender; tarsal segments smooth above; fifth hindtarsal segment rather deeply emarginate, the lobes very slender, the outer longer than the inner; aedeagus unknown. Length: $8 \mathrm{~mm}$; maximum width: $2.8 \mathrm{~mm}$.

Holotype $q$ (unique), Selminum tem Cave (station 1), Behrman Mountains, near Tifalmin, W. Sepic Province, NEW GUINEA, P. Chapman, xi.1975.

The vestigial eyes, long mandibles and slender appendages will separate caecum from all other described species of Gastragonum but despite these 


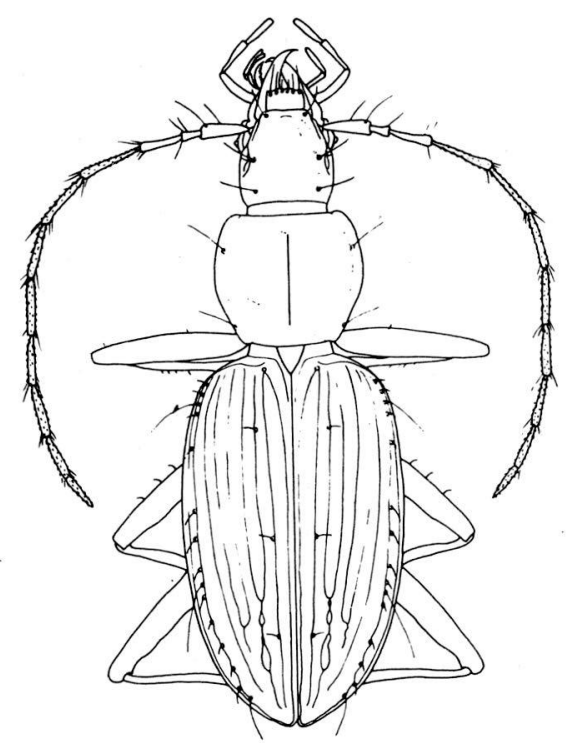

Fig. 2. Gastragonum caecum sp. n., holotype female.

aberrant features, I have no hesitation in referring the new species to this genus. According to Darlington (1952), the six species of Gastragonum he described, with the possible exception of laevisculptum, form a natural mesophile group more or less confined to the mountains of New Guinea and it is therefore not at all surprising that this particular stock should also have populated highland caves. These caves are comparatively cool by tropical standards, the temperature of the most extensive of them, the $20-\mathrm{km}$ long Selminum tem, where G. caecum occurred, being about $13.5^{\circ} \mathrm{C}$. Thus they would appear to offer ideal conditions for the development of troglobitic derivatives of local geophilous forms.

PSEUDOZAENA (TRICHOZAENA subgen. n.) CAVICOLA sp. n. (Figs. 3, 5)

Elongate, parallel; largely shining piceous-black but legs lighter, reddishbrown.

Head not large (for the genus), with three small setae in a triangle beside each eye; eyes rather small but prominent, enclosed by well marked orbits behind, the latter setose; mandibles broad at base but acutely pointed and somewhat porrect, inwardly denticulate; labrum transverse, subtruncate, 10-setose anteriorly; clypeus bisetose; antennae short, moniliform; tooth of mentum broad but pointed. Pronotum cordate, transverse, the disc convex; margins widely explanate, transversely strigose, 4-setose anteriorly; base depressed, transversely strigose; anterior angles sharp, somewhat advanced; posterior angles 


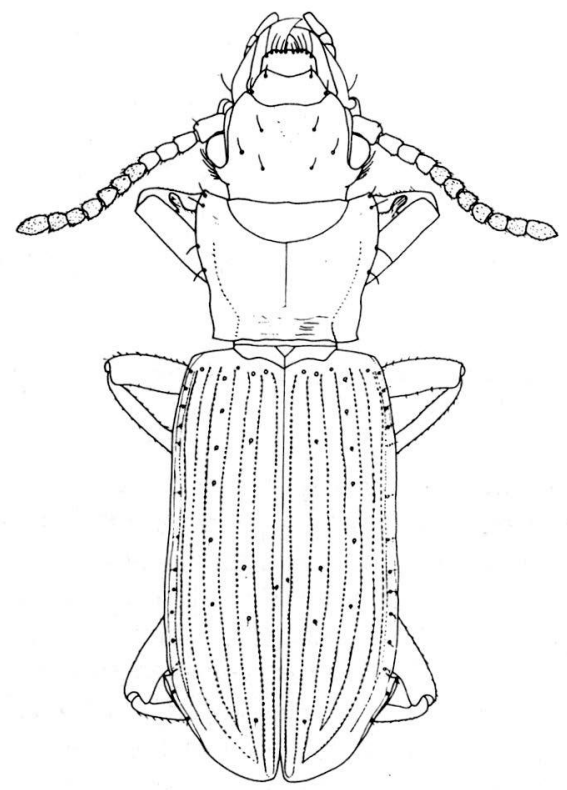

Fig. 3. Pseudozaena (Trichozaena) cavicola subgen. et sp. n., paratype male.

dentiform; median line very lightly impressed. Elytra elongate, parallel; humeri angulate but not dentate; striae complete, rather deep, strongly punctate; scutellary strioles wanting; intervals mooth, moderately convex, the first, third and fifth with small setiferous pores, otherwise similar to the others; hindwings fully formed; tarsi short but slender, sparsely setose above and below, the claws exceptionally long; male anterior tarsi unmodified; adeagus: Fig. 5. Length: 11-16 mm; maximum width: 3-4 mm.

Holotype ơ, Kabase Cave, Sohum Village, NEW IRELAND, P. Beron, 24.xi.1975. Paratypes, 82, both sexes (females greatly predominating), same data as holotype, in the Zoological Institute, Sofia; the British Museum (Natural History), London; the Museum of Comparative Zoology, Harvard, U.S.A.; the Bernice P. Bishop Museum, Honolulu, Hawaii, U.S.A.; the Australian National Insect Collection, Canberra; and in the author's collection. The species was very plentiful in guano under an ambient temperature of $24-25^{\circ} \mathrm{C}$.

Darlington (1962) recognised only one polytypic species of Pseudozaena Castelnau, namely orientalis Klug, with ssp. opaca Chaudoir in New Guinea (and islands to the north) and ssp. tricostata Montrouzier in New Britain and the Solomon Islands. $P$. cavicola is abundantly distinct from these by virtue, inter alia, of its setose vertex, labrum and frons; its less developed mandibular dentition; and its regular elytral striation. These evidently primitive attributes, especially the retention of tactile setae, exclude the species from Pseudozaena in Bänninger's (1927) generic key but, on the other hand, do not allow it to run 

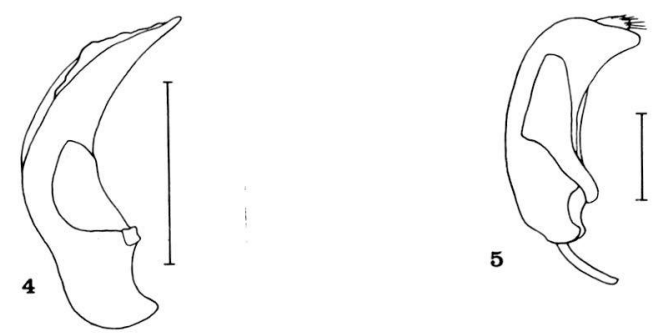

Figs. 4-5. Aedeagi in left lateral view: 4, Speagonum mirabile; 5, Pseudozaena (Trichozaena) cavicola. Scale-lines $=0.5 \mathrm{~mm}$.

smoothly to another genus. The new species is obviously the type of a primitive group within Pseudozaena, for which I propose Trichozaena subgen. $\mathrm{n}$.

A very similar and apparently undescribed species, also referable to this subgenus, is represented in the collections of the British Museum by two examples from Penang, Malaysia. In these, however, the labrum is much shorter and more transverse than in $P$. (T.) cavicola; the eyes are less prominent, with larger orbits more abruptly angled at the neck; and the elytral humeri are evidently denticulate. These specimens were taken at light and since $P$. (T.) cavicola shows entirely comparable development of eyes and wings, it seems hardly likely to be entirely restricted to caves but like guanophiles in general, is most probably a troglophile.

\section{SUMMARY}

Speagonum mirabile gen. et sp. n. and Gastragonum caecum sp. n. are described as troglobites from caves in the Behrman Mountains of west New Guinea; Pseudozaena (Trichozaena subgen. n.) cavicola sp. $\mathrm{n}$. is a troglophile from New Ireland.

\section{RESUME}

Speagonum mirabile gen. et sp. n. et Gastragonum caecum sp. n. sont décrites comme étant des espèces troglobies des grottes des Monts Behrman de l'Ouest de la Nouvelle-Guinée; Pseudozaena (Trichozaena subgen. n.) cavicola sp. n. est un troglophile de Nouvelle-Irlande.

\section{REFERENCES}

BÄNNINGER, M., 1927: Die Ozaenini (Col. Carab.). 10. Beitrag zur Kenntnis der Carabinae. Dtsch. ent. Z., 1927: 177-216.

BARR, T. C., 1960: The Cavernicolous Beetles of the Subgenus R hadine, Genus Agonum (Coleoptera: Carabidae). Amer. Midland Nat., 64: 45-65. 
DARLINGTON, P. J., 1952: The Carabid Beetles of New Guinea Part II. The Agonini. Bull. Mus. comp. Zool., 107: 89-252.

DARLINGTON, P. J., 1962: The Carabid Beetles of New Guinea Part I. Cicindelinae, Carabinae, Harpalinae through Pterostichini. Bull. Mus. comp. Zool., 126: 321-564.

DARLINGTON, P. J., 1971: The Carabid Beetles of New Guinea Part IV. General Considerations; Analysis and History of the Fauna; Taxonomic Supplement. Bull. Mus. comp. Zool., 142: 129-337. 